\title{
Epidermal Growth Factor Increases Antioxidant Enzyme and Surfactant System Development during Hyperoxia and Protects Fetal Rat Lungs In Vitro from Hyperoxic Toxicity
}

\author{
LALITHA T. PRICE, YOUWEI CHEN, AND LEE FRANK
}

Pulmonary Research Division, University of Miami School of Medicine, Miami, Florida 33136

\begin{abstract}
Epidermal growth factor (EGF) has been shown to accelerate fetal lung maturation in rabbits, lambs, and rhesus monkeys in vivo and increase surfactant synthesis in vitro. Its effect on the maturation of the lung antioxidant enzyme system, however, is unknown. We studied the effect of EGF ( $10 \mathrm{nM})$ on 19-d fetal rat lung explant cultures in serum-free medium in air $/ 5 \% \mathrm{CO}_{2}$ or $>90 \%$ $\mathrm{O}_{2} / 5 \% \mathrm{CO}_{2}$ compared with similarly grown control cultures in air or hyperoxia at $72 \mathrm{~h}$. Fetal lung activities of superoxide dismutase and catalase were unchanged by EGF in air, whereas glutathione peroxidase activity was significantly decreased ( $p<0.05$ versus air control). However, in hyperoxia, EGF-treated fetal lung cultures had significantly elevated superoxide dismutase and catalase activities $(p<0.01)$ versus $\mathrm{O}_{2}$-exposed controls, and glutathione peroxidase activity similar to that of controls. The mRNA levels for all the antioxidant enzymes showed patterns similar to the enzyme activities except in the case of $\mathrm{Cu}, \mathrm{Zn}$ superoxide dismutase mRNA, which increased in EGF-air cultures. EGF decreased the rate of ${ }^{3} \mathrm{H}$-choline incorporation into disaturated phosphatidylcholine in air $(p<0.01$ versus air control), but increased disaturated phosphatidylcholine synthesis in response to hyperoxia $(p<0.01$ versus $\mathrm{O}_{2}$ control). The histologic appearance of EGF-treated cultures in $\mathrm{O}_{2}$ was superior to that of $\mathrm{O}_{2}$-exposed controls, which showed thickened septal walls, decreased surfactant in the air spaces, and epithelial cell mitochondrial swelling. EGF therefore accelerates antioxidant enzyme and disaturated phosphatidylcholine maturation under hyperoxic conditions and protects fetal rat lung cultures from hyperoxic injury. This accelerated $\mathrm{O}_{2}$-dependent maturation by EGF occurs at the pretranslational level. These findings could have clinical implications for premature infants requiring $\mathrm{O}_{2}$ therapy and at risk for bronchopulmonary dysplasia because of immature pulmonary antioxidant defenses. (Pediatr Res 34: 577-585, 1993)
\end{abstract}

\section{Abbreviations}

EGF, epidermal growth factor

AOE, antioxidant enzyme

DSPC, disaturated phosphatidylcholine

SOD, superoxide dismutase

GP, glutathione peroxidase

CAT, catalase

GAPDI, glyceraldehyde 3-phosphate dehydrogenase

Received October 15, 1992: accepted June 4, 1993.

Correspondence and reprint requests: Lalitha T. Price, Ph.D., Pulmonary Research (R-120). University of Miami School of Medicine, P.O. Box 016960. Miami, FL 33136 .

Supported by funds from Pulmonary Research Center. Departments of Medicine and Pediatrics
RDS, respiratory distress syndrome

LDI, lactate dehydrogenase

TNA, total nucleic acid

In all mammalian species studied to date, there is a late gestational increase in surfactant and a parallel increase in the AOE system of the lungs $(1,2)$. These late gestational biochemical changes prepare the fetal lungs for the transition from a fluidfilled state in a relatively $\mathrm{O}_{2}$-poor intrauterine environment to air breathing in a relatively $\mathrm{O}_{2}$-rich environment at birth (3). The prematurely born infant with a poorly developed surfactant system is prone to develop severe RDS and requires early mechanical ventilation combined with $\mathrm{O}_{2}$ therapy. Prolonged $\mathrm{O}_{2}$ therapy is associated with the development of chronic lung disease or bronchopulmonary dysplasia believed to be due in part to a poorly developed AOE defense system to counteract toxic $\mathrm{O}_{2}$ radical species generated by hyperoxia $(3,4)$.

Lung maturation is known to be regulated or modulated by a number of hormones, among them the polypeptide EGF (5). In vivo, EGF has been shown to enhance maturation of alveolar type II cells and increase surfactant production in fetal rabbits $(6,7)$ and rhesus monkeys $(8)$. Similarly, EGF increased morphologic maturation of the fetal lung and decreased RDS in fetal lambs (9). EGF also caused similar effects on surfactant system maturation in vitro in rat fetal lung explant cultures (10) and isolated fetal alveolar type II cells (11). There is no information to date on the effects of EGF on fetal lung AOE system maturation. We investigated whether EGF accelerates the normal late gestational maturation of the AOE in parallel with the surfactant system in fetal rat lung cultures under serum-free conditions. Because the AOE response may be modulated by hyperoxia (12. 13 ), and because fetal lung exposure to hyperoxia is essentially what occurs clinically in $\mathrm{O}_{2}$-requiring very premature infants, we also investigated the effect of hyperoxia plus EGF on the $A O E$ and surfactant system in these lung explant cultures.

\section{MATERIALS AND METHODS}

Animals. Timed pregnant Sprague-Dawley albino rats were obtained by placing two females and one male together overnight and checking vaginal smears for the presence of sperm the next morning (considered d 0). On the 19 th $\mathrm{d}$, pregnant females were anesthetized with an i.p. injection of ketamine:xylazine, $90 \mathrm{mg} /$ $\mathrm{kg}: 10 \mathrm{mg} / \mathrm{kg}$ (Ketalar, Parke-Davis, Morris Plains, NJ, and Gemini, Rugby Laboratories, Inc., Rockville Center, NY). Fetuses were obtained by hysterotomy under sterile conditions. Fetuses were given an i.p. overdose of pentobarbital and their lungs were perfused with cold sterile $0.9 \% \mathrm{NaCl}$ and transferred to chilled 
serum-free Waymouth MB 752/1 medium (Media Facility, Department of Microbiology, University of Miami School of Medicine) containing $100 \mathrm{U} / \mathrm{mL}$ penicillin and $100 \mu \mathrm{g} / \mathrm{mL}$ streptomycin. Lungs from three to four litters were pooled for each experiment. All animal use protocols were preapproved by the University of Miami Animal Welfare Committee.

Lung explant culture method. The lung explant culture technique described by Gross et al. (14) was followed with modifications. Briefly, perfused lungs were chopped into 0.1- to 0.2$\mathrm{mm}$-thick sections with a Mcllwain tissue chopper (Brinkman Instruments, Westbury, NY) and suspended in chilled serumfree Waymouth medium. Cultures were grown on $60 \times 15-\mathrm{mm}$ plastic dishes (Falcon, Oxnard, CA) whose surfaces were scratched with a sterile scalpel. Approximately $100 \mathrm{mg}$ of wet tissue in $0.5 \mathrm{~mL}$ of medium were placed in each dish and incubated at $37^{\circ} \mathrm{C}$ in a humidified $\mathrm{CO}_{2}$ incubator (Bellco Glass Inc., Vineland, $\mathrm{NJ}$ ) in $95 \%$ air $/ 5 \% \mathrm{CO}_{2}$ for $2 \mathrm{~h}$. After $2 \mathrm{~h}$ of incubation, the unattached tissue was aspirated off and $2 \mathrm{~mL}$ of medium at $37^{\circ} \mathrm{C}$ was added.

$\mathrm{O}_{2}$ exposture and treatment with $E G F$. Explants from 19-d fetal lungs were grown in the presence or absence of $10 \mathrm{nM} E G F$ (human recombinant EGF, United States Biochemicals, Cleveland, $\mathrm{OH}$ ) in serum-free Waymouth's medium. At $24 \mathrm{~h}$ of incubation, half the cultures from control and EGF-treated groups were transferred to an atmosphere of $90 \pm 2 \% \mathrm{O}_{2} / 5 \%$ $\mathrm{CO}_{2}$ in a tri-gas incubator (Nuaire Inc., Plymouth, MN) and incubation was continued until $72 \mathrm{~h}$, with fresh medium $\pm \mathrm{EGF}$ added daily. Oxygen and $\mathrm{CO}_{2}$ percentages were monitored with Beckman model OM-11 and LB-2 gas analyzers (Beckman Instruments, Inc., Schiller Park, IL). Earlier studies in our laboratory (15) and others (16) have reported medium $\mathrm{Po}_{2}$ of 150 and $600 \mathrm{~mm} \mathrm{Hg}(20$ and $80 \mathrm{kPa})$ in cultures exposed to $95 \%$ air and $95 \% \mathrm{O}_{2}$, respectively.

Preparation of tissue for lung biochemical analyses. At the different time intervals indicated (see Results), medium was aspirated and cultures were rinsed with $0.9 \% \mathrm{NaCl}$ and gently scraped off into preweighed $12 \times 15-\mathrm{mm}$ test tubes. Tissue from two to three dishes was combined for each sample. The tissue was pelleted by centrifugation at $4^{\circ} \mathrm{C}(\approx 1000 \times g, 10 \mathrm{~min})$ and the pellet was dried under vacuum overnight (Speed Vac SC100, Savant Instruments Inc., Farmingdale, NY). The dricd pellet was weighed and resuspended in $0.9 \% \mathrm{NaCl}$ and homogenized for $30 \mathrm{~s}$ in an Omni 2000 model homogenizer (Omni International Inc., Waterbury, CT). Aliquots were taken for lipid extraction and DSPC analysis. The remaining homogenate was diluted in $50 \mathrm{mM}$ potassium phosphate buffer, $\mathrm{pH} 7.5$, and centrifuged at $27000 \times g$ for $45 \mathrm{~min}$, and the supernatants were kept frozen at $-20^{\circ} \mathrm{C}$ until EGF-treated and control samples were analyzed at the same time for activities of SOD, CAT, GP, and LDH. Aliquots were also analyzed for DNA (17) and protein content (18) before centrifugation.

$A O E$ activities. SOD activity was measured by the xanthinexanthine oxidase assay (in the presence of $0.015 \mathrm{mM}$ cyanide). The rate of reduction of cytochrome $c$ at $550 \mathrm{~nm}$ (19) measured the total activities of $\mathrm{Cu}, \mathrm{Zn}$, and $\mathrm{MnSOD}$. CAT activity was assayed by the rate of reduction of $\mathrm{H}_{2} \mathrm{O}_{2}$ at $240 \mathrm{~nm}(20)$, and GP activity was measured by the rate of oxidation of NADPH at 340 $\mathrm{nm}$ using cumene hydroperoxide as substrate (21). Both Sedependent and Se-independent GP activities are measured by this method. AOE activities were expressed as U/mg DNA.

LDH assay. LDH activity was measured in both the media and tissue homogenates of cultures using a spectrophotometric assay kit (cat. no. 340-UV, Sigma Chemical Co., St. Louis, MO). Results were expressed as percent of total LDH activity in the medium.

Lipid extraction and DSPC analysis. Lipids were extracted from aliquots of tissue homogenates according to Bligh and Dyer (22). DSPC was separated from the total lipids (23) and analyzed for inorganic phosphorus (24). A known quantity of ${ }^{14} \mathrm{C}$-dipalmitoyl phosphatidylcholine (New England Nuclear Research
Products, Boston. MA) was added during extractions to estimate recovery. Results were expressed per mg dry tissue weight.

Rate of ${ }^{3} H$-choline incorporation into DSPC. Explants were grown for $67 \mathrm{~h}$ as described above. At $67 \mathrm{~h}$, medium was aspirated and fresh medium containing $2 \mu \mathrm{Ci} / \mathrm{mL}$ [methyl- ${ }^{3} \mathrm{H}$ ]choline chloride (New England Nuclear Research Products), sp act 81 $\mathrm{Ci} / \mathrm{mmol}$, was added and incubation was continued until $72 \mathrm{~h}$. At $72 \mathrm{~h}$, medium was collected in silanized glass tubes and stored at $-20^{\circ} \mathrm{C}$ until lipid extraction. The tissue was rinsed with $0.9 \%$ $\mathrm{NaCl}$, scraped off into silanized glass tubes, and vacuum-dried overnight. Lipid extraction and DSPC separation were performed separately in the medium and tissue homogenates as described just above. The DSPC extract was counted for ${ }^{3} \mathrm{H} /{ }^{14} \mathrm{C}$ radioactivity using a dual-label program in a Tri-Carb model 1900 TR liquid scintillation analyzer (Packard Instrument Co., Meriden, CT). The ${ }^{3} \mathrm{H}$ counts were corrected for losses during extraction using ${ }^{14} \mathrm{C}$ counts, and total ${ }^{3} \mathrm{H}$ counts in the medium and tissue were calculated. Results were expressed as dpm incorporated per mg protein.

"I-thymidine incorporation into DNA. Cultures were grown for $48 \mathrm{~h}$ in the presence or absence of EGF in air or $90 \% \mathrm{O}_{2}$ as described earlier. At $48 \mathrm{~h}$, medium was replaced by fresh medium containing $1 \mu \mathrm{Ci}$ [methyl- ${ }^{3} \mathrm{H}$ ] thymidine (New England Nuclear Research Products, sp act $=80.5 \mathrm{Ci} / \mathrm{mmol}$ ) and $10 \mu \mathrm{g}$ of unlabeled thymidine (Sigma Chemical Co.) per $\mathrm{mL}$ and incubated for $24 \mathrm{~h}$. At the end of incubation, cultures were rinsed twice with cold PBS and scraped off in the same buffer and homogenized as mentioned earlier. The DNA was precipitated with $10 \%$ cold trichloroacetic acid, redissolved in $0.8 \mathrm{~N} \mathrm{NaOH}$, and neutralized with $1.0 \mathrm{~N} \mathrm{HCl}$. Aliquots were counted for ${ }^{3} \mathrm{H} \mathrm{dpm}$. Protein was quantitated in aliquots of $0.8 \mathrm{~N} \mathrm{NaOH}$-soluble precipitate by Lowry's method. Results were expressed as ${ }^{3} \mathrm{H}$ $\mathrm{dpm}$ incorporated per $\mathrm{mg}$ protein.

(RN.1 preparations. Rat lung Cu,ZnSOD cRNA was prepared as described previously (25). For preparation of CAT cRNA (26), a 1.1-kb PstI fragment of rat CAT cDNA clone, PM J1010 (27), was subcloned into pGEM-3Z (Promega Corporation, Madison, WI). After transformation in Escherichia coli JM 109 and linearization of the recombinant plasmid, a ${ }^{35} \mathrm{~S}$-labeled antisense cRNA probe was synthesized using SP6 RNA polymerase and [ $\left.{ }^{35} \mathrm{~S}\right]-$ uridine triphosphate (New England Nuclear Research Products, Boston, MA). An unlabeled sense cRNA was synthesized using T7 RNA polymerase.

For GP cRNA preparation (26), the plasmid DNA pkS-cGP1 , carrying a $\approx 0.9-\mathrm{kb}$ fragment of GP cDNA (28), was transformed directly in $E$. coli JM109. After linearization of the recombinant plasmid, ${ }^{35} \mathrm{~S}$-labeled antisense cRNA was prepared using T7 RNA polymerase and [ $\left.{ }^{35} \mathrm{~S}\right]$-uridine triphosphate, and unlabeled sense cRNA was synthesized using T3 polymerase.

The GAPDH cDNA clone used for preparation of GAPDH cRNA was a kind gift from Dr. Ph. Fort, Laboratoire de Biologie Moleculaire, Universite des Sciences et Techniques du Languedoc, Montpellier Cedex, France. The PstI fragment of rat cDNA clone (29) was subcloned into pGEM-3Z and ${ }^{35} \mathrm{~S}$-labeled sense cRNA and unlabeled antisense cRNA strands were synthesized as detailed above for CAT cRNA preparation.

AOE mRNA quantitations. mRNA for Cu, ZnSOD, GP. CAT, and GAPDH were quantitated in the TNA extracts of explant culture homogenates by solution hybridization according to Durnam and Palmiter (30). Tissue was homogenized in $1 \times$ SET buffer ( $1 \%$ SDS, $10 \mathrm{mM}$ Tris, pH 7.5 , and $5 \mathrm{mM}$ EDTA) in the presence of $200 \mu \mathrm{g} / \mathrm{mL}$ proteinase K (GIBCO-BRL, Gaithersburg, MD). A known amount $(\approx 3500 \mathrm{cpm})$ of $\left[{ }^{3} \mathrm{H}\right]-(\alpha$-actin cRNA was added during TNA extractions to estimate mRNA recoveries. The homogenates were incubated at $45^{\circ} \mathrm{C}$ for $1 \mathrm{~h}$, extracted with chloroform/phenol, and precipitated with ethanol. The ethanol-precipitated pellet was redissolved in RNase-free $\mathrm{H}_{2} \mathrm{O}$ at $68^{\circ} \mathrm{C}$ and stored at $-70^{\circ} \mathrm{C}$ until solution hybridization. Aliquots of TNA extracts were allowed to hybridize with the labeled cRNA probes in the hybridization mixture at $68^{\circ} \mathrm{C}$ for 
$16 \mathrm{~h}$. The unhybridized cRNA probes were digested at $55^{\circ} \mathrm{C}$ for $1 \mathrm{~h}$ with $8 \mathrm{U} / \mathrm{mL} \mathrm{S}$ nuclease and $100 \mathrm{U} / \mathrm{mL} \mathrm{T}_{1}$ ribonuclease (GIBCO-BRL) in the presence of $100 \mu \mathrm{g} / \mathrm{mL}$ salmon testes DNA (Sigma). The hybridized cRNA were precipitated with trichloroacetic acid, filtered on Whatman GF/C filters, and counted in Optifluor-O (Packard, Providence, RI). Unlabeled sense cRNA were used to construct standard curves for each AOE mRNA and for the GAPDH mRNA. mRNA were expressed as molecules per mg DNA.

Light microscopy and transmission electron microscopl. At different time intervals, explant cultures were fixed in a commercial fixative (Decal Chemical Corporation, Congers, NY) overnight. Paraffin-embedded tissues were sectioned to 3- to 4$\mu \mathrm{m}$ thickness and stained with hematoxylin and eosin, and coded slides were observed under a light microscope for evidence of lung maturation.

For morphometric assessment of the hematoxylin and eosinstained lung explants at $72 \mathrm{~h}$, coded slides were examined using a standard integrating morphometric eyepiece with seven equal lines and 42 intercept bars (Carl Zeiss, Inc., Thornwood, NY). Random fields were examined at $\times 400$ magnification, with $15-$ 20 fields (explants) counted per slide. A field was counted as long as there were some patent air spaces present. We counted the number of times the intercept bars fell on an air space per field and the number of times the lines were crossed by tissue septa per field. Percent air space was calculated by:

$$
\% \text { air space }=\mathrm{P}_{\mathrm{A}} /\left(\mathrm{P}_{\mathrm{A}}+\mathrm{P}_{\mathrm{t}}\right) \times 100
$$

where $P_{A}$ is the number of intercept bars hitting air and $P_{T}$ the number of intercept bars hitting tissue. $\mathrm{L}_{\mathrm{M}}$ or mean linear intercept (= average air space diameter) was calculated by:

$$
\mathrm{L}_{\mathrm{M}}=\frac{\text { length of line } \times \text { no. of lines } \times \text { no. of fields }}{\text { no. of tissue interceptions }}
$$

where length of line $=0.21 \mathrm{~mm}$, number of lines $=7$, and number of fields $=15-20 /$ slide $(31,32)$.

For electron microscopic examination, explants were fixed overnight in $2 \%$ glutaraldehyde in $0.1 \mathrm{M}$ cacodylate buffer, $\mathrm{pH}$ 7.4. They were then postfixed in a $2 \%$ solution of osmium tetroxide in cacodylate buffer and dehydrated by passing through grades of ethyl alcohol. The dehydrated tissue was embedded in Araldite 502 and ultrathin sections were cut with an ultramicrotome (Sorvale Porter-Blum model MT-2, DuPont Co., Wilmington, DE), stained with uranyl acetate and lead citrate, and observed under transmission electron microscopy (model CX100, Jeol USA, Inc., Peabody, MA).

Statistical analysis. For each parameter measured, the mean \pm SD or SEM was calculated using the pooled $n$ value from two to three separate experiments with three to four samples per experiment $(n=6-12)$. Because each sample in an experiment was derived from different fetal animals, each represents the response of different fetal rat lungs to experimental conditions, and thus each sample was treated independently as a separate $n$ for statistical analysis. Also, because variation between the mean values from the separate experiments was in general no greater than the intrasample variation for each separate experiment, a total $n$ value reflecting the number of individual samples tested for each parameter was considered justifiable.

Comparison of data for the four test groups was by analysis of variance. Intergroup differences were detected by Duncan's multiple range test with Kramer's extension $(33,34)$. Statistical significance between group values was set at $p<0.05$.

\section{RESULTS}

$A O E$ activities and $A O E M R N A$ in lung explant cultures. The control 19-d fetal rat lung cultures grown in serum-free medium in an atmosphere of air $/ 5 \% \mathrm{CO}_{2}$ showed significant increases in AOE activities of SOD, CAT, and GP from 0 to $72 \mathrm{~h}$ (Fig. 1) similar to the late gestational increases reported in vivo $(1,2)$.

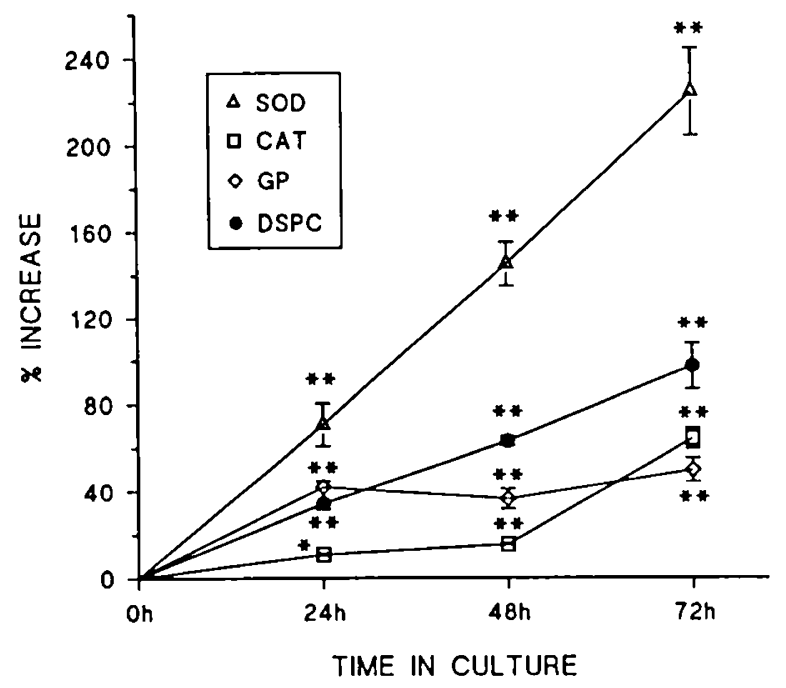

Fig. 1. Increases in AOE activities and DSPC content of 19-d fetal rat lung explant cultures. Explants were grown in serum-free Waymouth MB 752/1 medium for $72 \mathrm{~h}$ in an atmosphere of $95 \%$ air $/ 5 \% \mathrm{CO}_{2}$. Values are percent increases compared with values for 0 -h cultures. which were (in enzyme $\mathrm{U} / \mathrm{mg}$ DNA) SOD $=25.8 \pm 2.1$, CAT $=73.8 \pm$ 5.6. GP $=0.175 \pm 0.02$, and DSPC $(\mu \mathrm{g} / \mathrm{mg}$ dry tissue $)=21.3 \pm 0.3$. Statistical significance at $p<0.05\left(^{*}\right)$ and at $p<0.01\left(^{* *}\right)$ is 0 -h cultures was determined by analysis of variance and Duncan's multiple range test ( $n=6-8$ per time point). The error bars in this and subsequent figures indicate SEM.

Untreated rat lung cultures exposed to $90 \% \mathrm{O}_{2}$ (from 24 to 72 h) had increased activities of SOD $(\uparrow 19 \%, p<0.05)$. CAT $(\uparrow 117 \%, p<0.01)$, and GP $(\uparrow 40 \%, p<0.01)$ at $72 \mathrm{~h}$ compared with (untreated) air-controls (Fig. 2). EGF treatment of lung cultures in air did not result in any changes in SOD or CAT activities, but a decrease in GP activity $(\downarrow 30 \%, p<0.05)$ occurred versus control-air cultures (Fig. 2). Upon $\mathrm{O}_{2}$ exposure of EGFtreated cultures, significant increases $(p<0.01)$ in SOD $(\uparrow 48 \%$ versus air-control; $\uparrow 51 \%$ versus air-EGF: $\uparrow 24 \%$ versus $\mathrm{O}_{2}$-control) and CAT $(\uparrow 198 \%$ versus air-control; $\uparrow 216 \%$ versus air-EGF; $\uparrow 37 \%$ versus $\mathrm{O}_{2}$-control) activities were observed (Fig. 2). Enzyme activity of GP was not significantly different from $\mathrm{O}_{2}-$ control cultures but was elevated when compared with air-grown cultures $(\uparrow 26 \%$ versus air-control, $p<0.05$; $\uparrow 63 \%$ versus airEGF, $p<0.01$; Fig. 2).

The mRNA levels for the three enzymes Cu,ZnSOD, CAT, and GP at $72 \mathrm{~h}$ under various experimental conditions are shown in Figure 3. The specific mRNA levels for CAT and GP followed a similar trend as their enzyme activities (i.e. an increase in mRNA level consistent with increased activity and vice versa). However, the increases in CAT and GP mRNA observed in $\mathrm{O}_{2}-$ control cultures were not statistically significant versus controlair cultures, whereas those observed in $\mathrm{O}_{2}$-EGF cultures were statistically significant verstus the other three groups (CAT) or versus EGF-air cultures (GP). The mRNA levels for $\mathrm{Cu}, \mathrm{ZnSOD}$, however, followed a different pattern: although the total SOD activity was unchanged in EGF-air cultures compared with control-air, the $\mathrm{Cu}, \mathrm{ZnSOD} \mathrm{mRNA}$ levels were significantly higher $(\uparrow 35 \%, p<0.01)$. In $90 \% \mathrm{O}_{2}$, as with SOD activity, Cu,ZnSOD mRNA levels were significantly elevated compared with airgrown cultures in both the control- $\mathrm{O}_{2}$ and $\mathrm{EGF}-\mathrm{O}_{2}$ groups, the mRNA level in EGF- $\mathrm{O}_{2}$ being further elevated compared with control- $\mathrm{O}_{2}$ cultures $(\uparrow 31 \%, p<0.05)$.

In contrast to the AOE mRNA, the mRNA content of GAPDH (a marker enzyme generally used for measuring nonspecific gene expression) was unaltered in control- $\mathrm{O}_{2}$ and EGF- $\mathrm{O}_{2}$ cultures, whereas the GAPDH mRNA levels in EGF-air cultures were significantly elevated (GAPDH mRNA molecules $\times 10^{12} / \mathrm{mg}$ DNA, mean $\pm \mathrm{SD}, n=6$ : control-air $=2.77 \pm 0.30$ versus 

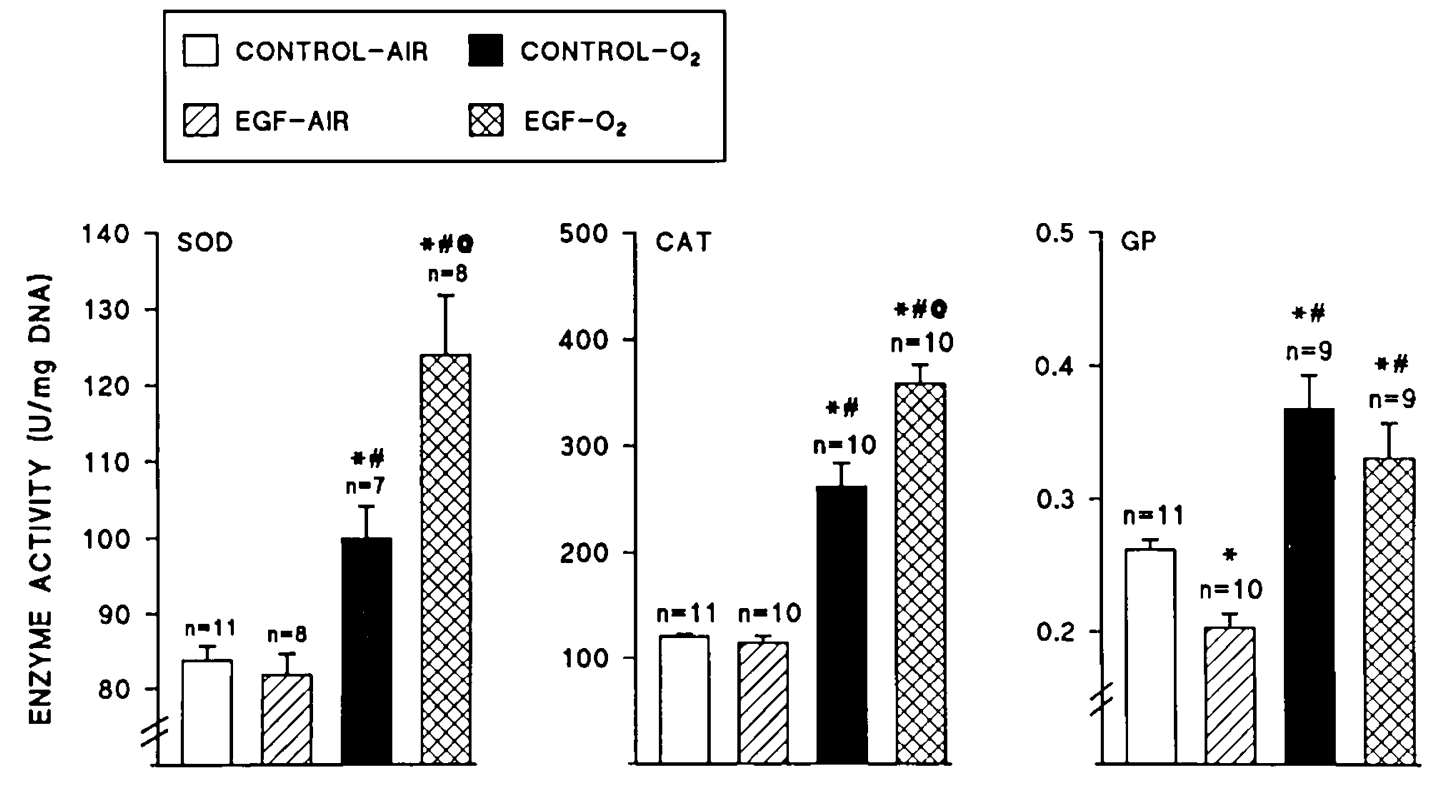

Fig. 2. Effect of EGF on AOE activities of 19-d fetal rat lung explant cultures in air or $90 \% \mathrm{O}_{2}$ at 72 h. Explant cultures treated with EGF (10 $\mathrm{nM}$ ) or untreated (control) were incubated for $24 \mathrm{~h}$ in $95 \%$ air $/ 5 \% \mathrm{CO}_{2}$. Half of the explant cultures were then exposed to $90 \% \mathrm{O}_{2} / 5 \% \mathrm{CO} 2$ and the other half maintained in air until $72 \mathrm{~h}$. Other details are described in Materials and Methods. Statistical significance at $p<0.05 \mathrm{us}$ control-air $\left({ }^{*}\right)$, is EGF-air (\#), and is control- $\mathrm{O}_{2}$ (@) was determined by Duncan’s multiple range test.
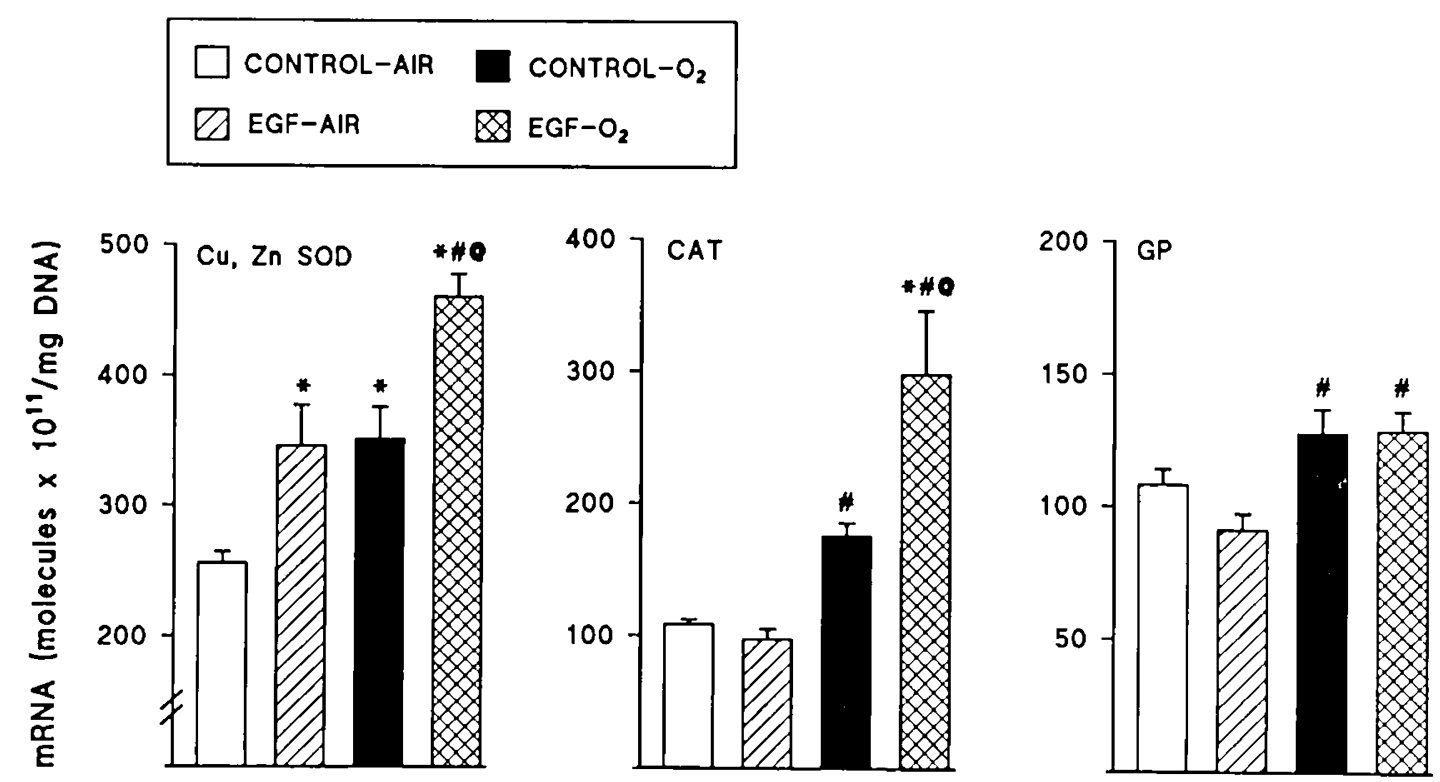

Fig. 3. Effect of EGF on AOE mRNA content of 19-d fetal rat lung explant cultures in air or $\mathrm{O}_{2}$ at $72 \mathrm{~h}$. See legend to Figure 2 for experimental details. Statistical significance at $p<0.05$ is control-air $(*)$, is EGF-air $(\#)$, and is control-O $(\Theta)$ was determined by Duncan`s multiple range test. $n=6$ per group.

control- $\mathrm{O}_{2}=2.14 \pm 0.64$ versus $\mathrm{EGF}-\mathrm{O}_{2}=2.58 \pm 0.61, p>$ 0.05 ; EGF-air $=4.28 \pm 0.80, p<0.01$, versus all the other groups).

DSPC synthesis and DSPC content. The DSPC content of 19$\mathrm{d}$ control lung culture grown in serum-free medium in air $/ 5 \%$ $\mathrm{CO}_{2}$ progressively increased from 0 to $72 \mathrm{~h}$ in culture in parallel with the AOE activities (Fig. 1), similar to in vivo findings (1,2). The rate of DSPC synthesis at $72 \mathrm{~h}$ as measured by ${ }^{3} \mathrm{H}$-choline incorporation (dpm incorporated/mg protein) was significantly decreased by EGF treatment in cultures maintained in air [control-air $=15035 \pm 795 ;$ EGF-air $=10725 \pm 1130 ;(\downarrow 40 \%), n=$ $6, p<0.01]$. This was accompanied by a similar decrease in DSPC content $(\mu \mathrm{g} / \mathrm{mg}$ tissue) [control-air $=33.3 \pm 8.0, n=6$ versus EGF-air $=25.6 \pm 4.0, n=9 ;(\downarrow 23 \%), p<0.05] . \mathrm{O}_{2}$ exposure of untreated cultures resulted in a small but significant increase in the rate of DSPC synthesis [control-O $=16485 \pm$ 980; ( $\uparrow 10 \%$ versus control-air $), n=6, p<0.05]$ whereas the increase observed in EGF treated cultures was much greater $\left[\mathrm{EGF}-\mathrm{O}_{2}=19880 \pm 1105, n=6,(\uparrow 85 \%\right.$ versus EGF-air; $\uparrow 32 \%$ versus control-air; $\uparrow 21 \%$ versus control- $\mathrm{O}_{2}$ ); $p<0.05$ or less in all cases]. These DSPC synthesis rates appear to correlate with the electron microscopic observations on lamellar body contents and air space surfactant (see below).

Histologic observations. We examined the tissue explants by light microscopy as well as electron microscopy to see whether the observed biochemical changes were associated with identifiable morphologic changes. Under a light microscope, the control cultures grown in air for $72 \mathrm{~h}$ showed morphologic changes such as an increase in air space, a decrease in mesenchymal tissue, and thinning of interstitial septa (Fig. 4. ). There was no micro- 


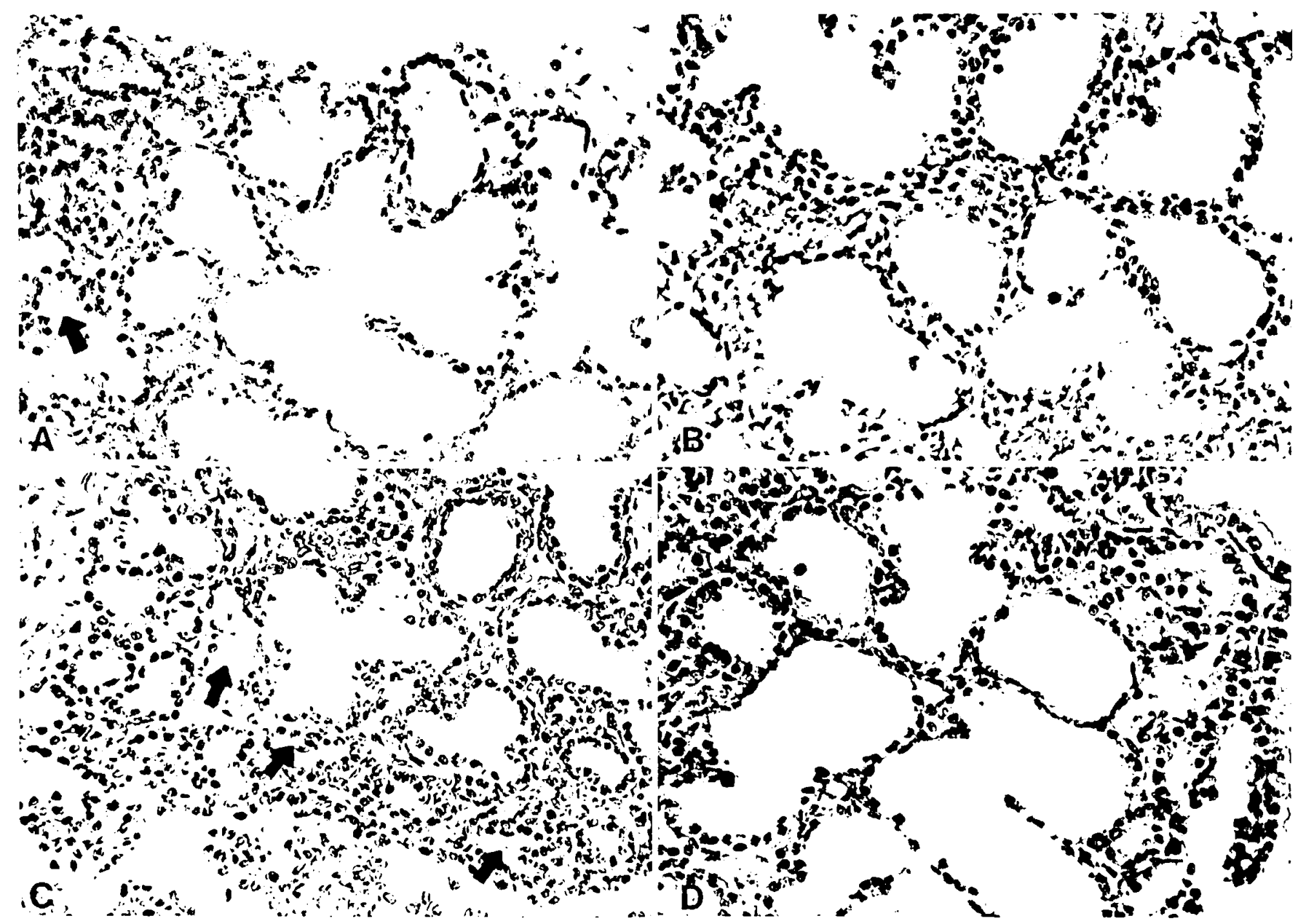

Fig. 4. Light microscopic appearance of 19-d fetal rat lung explant cultures treated with $10 \mathrm{nM}$ EGF or untreated (control), grown in air or 90\%; $\mathrm{O}_{2}$, at $72 \mathrm{~h}$. A. Control-air: $B$. EGF-air; $C$. control- $\mathrm{O}_{2}: D$, EGF-O . Control-air (A) and EGF-air (B) cultures appear quite similar by light microscopy except for the more homogeneously sized air spaces in the EGF-air lungs and typical small areas of air space collapse in the control-air explants (arrow). Note the increased thickness of interstitial septa in the $\mathrm{O}_{2}$-exposed controls $(C)$ compared with the EGF- $\mathrm{O}_{2}$ cultures $(D)$ ). which closely resemble the air cultures $(A$ and $B$ ). Note also the areas of collapsed and partially collapsed air spaces in the control-Oz lung explants (arrows). Hematoxylin and eosin stain. Magnification $\times 250$.

scopic evidence of gross tissue necrosis up to $72 \mathrm{~h}$ in any of the explants. However, the control- $\mathrm{O}_{2}$ cultures revealed significant morphologic differences such as a large proportion of collapsed air spaces and much thicker interstitial septa (Fig. 4C). In contrast, EGF-O $\mathrm{O}_{2}$ cultures had comparatively few collapsed air spaces and consistently thinner interstitial septa (Fig. 4D).

The percentage of LDH activity in the medium was high at 24 h (average for all cultures $\approx 35 \%$ ) but decreased consistently reaching $4-12 \%$ at $72 \mathrm{~h}$ (Table 1 ). This initial high LDH activity is likely due to a large proportion of cut edges resulting from thin sectioning of tissue (14), which seemed to repair during the culture period. The percentage of $\mathrm{LDH}$ release in control-O exposed cultures was not significantly different from control-air cultures, suggesting that $90 \% \mathrm{O}_{2}$ for $48 \mathrm{~h}$ was not extremely cytotoxic for these cultures. The percentage of LDH activity in the medium was substantially lower in the EGF-O 2 group compared with the other three groups $\left(\mathrm{EGF}-\mathrm{O}_{2}=3.7 \pm 0.7 \%, n=6\right.$ : $p<0.01$ ), consistent with the improved histologic appearance.

Table 1. Effect of EGF (10 nit) on LDH release and morphometry in l9-d fetal rat lung explant cultures grown in air or

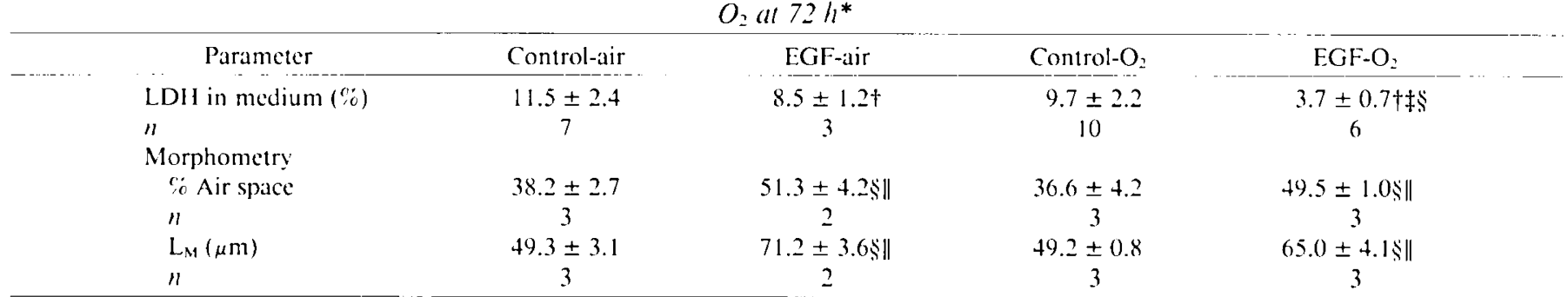

* Values are mean $\pm \mathrm{SD}$. $\mathrm{L}_{\mathrm{N}}$. mean linear intercept or mean air space diameter. For morphometry, $n=$ no. of experiments, with $15-20$ fields (coded lung explants) examined per experiment.

$\dagger p<0.05$ or less is control-air.

$\ddagger p<0.01$ is EGF-air.

$\$ p<0.01$ is control- $\mathrm{O}_{2}$.

$\| p<0.01$ is control-air 


Table 1 also summarizes the morphometric data in fetal rat ung cultures at $72 \mathrm{~h}$ under various experimental conditions. Morphometrically, EGF-air cultures at $72 \mathrm{~h}$ had an increased sercentage of air space $(\uparrow 34 \%, p<0.01)$ and larger mean air space diameter $(\uparrow 44 \%, p<0.01)$ i'ersus control-air cultures. The norphometric parameters (percentage of air space and mean air ;pace diameter) of patent air spaces in control- $\mathrm{O}_{2}$ cultures did tot differ significantly from those in control-air cultures, whereas $\Xi \mathrm{GF}-\mathrm{O}_{2}$ cultures had a significantly increased percentage of air ;pace $(\uparrow 35 \%, p<0.01)$ and mean air space diameter $(\uparrow 32 \%, p<$ ).01) compared with control- $\mathrm{O}_{2}$ cultures.

Electron microscopic observations provided further support hat the 19-d lung cultures underwent histologic maturation Juring the culture period. At $0 \mathrm{~h}$, the cells lining the air spaces ippeared columnar, with large dense nuclei, abundant glycogen itores, and only a few nascent lamellar-type bodies (Fig. 5A). At $72 \mathrm{~h}$, the control-air cultures had considerably less dense nuclei, nuch smaller glycogen stores, increased lamellar body content, and considerable osmiophilic material in the air spaces (Fig. $5 B$ ). The ultrastructural appearance of EGF-air cultures (Fig. $5 C$ ) ndicated poorer maturation of epithelial cells with very few amellar bodies and proportionately more glycogen stores in the :ells (consistent with the DSPC findings noted above). The $\mathrm{O}_{2}-$ :xposed cultures at $72 \mathrm{~h}$ showed improved maturation of type II :ells, with increased lamellar body content (Fig. $5 D$ and $E$ ), again :onsistent with the increased rate of DSPC synthesis described sarlier. However, in control- $\mathrm{O}_{2}$ cultures, only a small amount of iurfactant was observed in the open air spaces, whereas the amellar bodies in type II cells were comparatively enlarged and tense in appearance (Fig. $5 D$ ). The mitochondria in $\mathrm{O}_{2}$-exposed control cultures were considerably swollen in comparison with ir-grown cultures, and many of the mitochondria also showed iberrant appearance of cristae. The EGF-treated cultures exposed - $90 \% \mathrm{O}_{2}$ showed improved maturation of type II cells and zreater lamellar body content than the other three groups. The ir spaces in EGF-O $\mathrm{O}_{2}$ cultures were filled with abundant surfacant material (Fig. $5 E$ ), consistent with the significantly increased JSPC synthesis. The appearance of mitochondria in EGF-O :ultures at $72 \mathrm{~h}$ was comparable with that in air-exposed cultures.

DNA and protein. Table 2 summarizes the effects of EGF reatment on fetal explant lung DNA synthesis, DNA and protein :ontent, and protein to DNA ratio in air and in hyperoxia. The DNA synthesis rate (measured by ${ }^{3} \mathrm{H}$-thymidine incorporation) Jetween 48 and $72 \mathrm{~h}$ was significantly higher in EGF-treated sultures both in air and in $\mathrm{O}_{2}$ compared with untreated cultures. Vo significant $\mathrm{O}_{2}$ effect was observed for either the control or he EGF-treated explants. Similarly, EGF treatment markedly ncreased the DNA and protein content of the explant cultures $\mathrm{n}$ air and in $\mathrm{O}_{2}$. The only significant $\mathrm{O}_{2}$ effect observed was in he elevated protein content of the $\mathrm{O}_{2}$-EGF explants.

\section{DISCUSSION}

By decreasing the thickness of the lung explants, we were able .0 avoid the high $\mathrm{O}_{2}$ requirement previously reported for fetal at lung cultures (14). This has enabled us to study the effect of EGF on biochemical and morphologic maturation of fetal lungs $\mathrm{n}$ air as well as in hyperoxia under serum-free conditions.

The effects of EGF on lung surfactant phospholipids, surfac- tant apoproteins, and morphologic maturation have been previously studied in various species $(6-11)$. To our knowledge, this is the first report of EGF's effect on the maturation of the fetal lung AOE system. Our study also shows that the effects of EGF are strongly modulated by hyperoxia (and vice versa).

We found that under lower $\mathrm{O}_{2}$ concentrations EGF had essentially no positive effect on the normal late gestational increase in fetal lung AOE activities (Fig. 2). Similarly, EGF did not increase the content or the synthesis of DSPC, which normally has a time course of maturation very similar to the chronology of $\mathrm{AOE}$ system maturation both in vitro and in vivo (1-3). However, EGF was able to substantially stimulate both lung biochemical systems under hyperoxia, resulting in increased $A O E$ activities and an augmented DSPC synthesis rate in response to high $\mathrm{O}_{2}$ challenge.

Gross et al. (10) have reported increases in DSPC synthesis by EGF in fetal rat lung cultures grown in $95 \% \mathrm{O}_{2}$ similar to the increases observed in the present study. However, the absence of definitely increased histologic maturation (Fig. $5 C$ ) and a clear decrease in DSPC synthesis in our EGF-air cultures is in contrast to the reported effects of in vivo administration of EGF in rats (35) and other fetal animal species (6-9). The differences observed between the above in vivo studies and our in vitro cultures may have been due to the absence of systemic hormonal interactions in our serum-free culture conditions. Similar to our present findings, others (36) have reported depressed numbers of lamellar bodies and retarded histologic maturation in fetal rat lung epithelial cells chronically exposed to EGF under normoxic, serum-free conditions. The above observations suggest that the effects of EGF on lung maturation under in vitro and in vivo conditions may be regulated by different mechanisms.

The ability of EGF to induce increased $\mathrm{AOE}$ activities under hyperoxic conditions appears similar to the $A O E$ response to hyperoxia recently reported in newborn rats prenatally treated with dexamethasone (37). In that study, dexamethasone did not alter lung $A O E$ levels in air-exposed neonatal rats, but resulted in significantly increased AOE responses to hyperoxic challenge and improved survival of the newborns in hyperoxia. The effect of EGF on fetal lung AOE in our explant cultures also appears similar to the effects reported in lungs of adults treated with low doses of bacterial endotoxin. When adults are maintained in air, no effect of endotoxin on pulmonary AOE activities is noted, whereas the endotoxin-treated adult lungs demonstrate significantly increased $\mathrm{AOE}$ activities (and AOE mRNA) on challenge with hyperoxia and become remarkably $\mathrm{O}_{2}$ tolerant (38). Whether or not the response of lung cells to dexamethasone, endotoxin, or EGF under hyperoxia is mediated by a common mechanism needs to be further studied.

Under hyperoxic conditions, EGF's stimulatory effect on AOE induction may have directly resulted in improved morphologic and histologic appearance of the lung cultures. The ability to augment lung $A O E$ activities under hyperoxia, rather than the basal AOE levels per se, has been repeatedly shown to be a key factor associated with the development of resistance to $\mathrm{O}_{2-}$ induced lung damage $(3,4,13,37-40)$. Even though fetal rat lungs grown in $90 \% \mathrm{O}_{2}$ in the present study were found to be able to increase their AOE activities in the absence of EGF, the $\mathrm{AOE}$ response was significantly greater when EGF was present in cultures, thus strongly suggesting an enhanced beneficial effect

Fig. 5. Transmission electron micrographs showing the effect of $10 \mathrm{nM}$ EGF on the histologic maturation and epithelial (type II) cell appearance of $19-\mathrm{d}$ fetal rat explant cultures grown in air or $90 \% \mathrm{O}_{2} .1,0$-h explants showing columnar epithelial cells filled with glycogen granules $(g)$ and very ew and immature lamellar bodies compared with cultures at $72 \mathrm{~h} ; B, 72$-h control-air; $C$, 72-h EGF-air; $D, 72-\mathrm{h}$ control-O $\mathrm{O}_{2} ;$ and $E, 72-\mathrm{h}$ EGF-O . Vote that the control-air explants at $72 \mathrm{~h}(B)$ have more lamellar bodies in type II cells plus more osmiophilic material (surfactant) in the air space :ompared with the more immature appearance of the EGF-air explants $(C)$. The control- $\mathrm{O}_{2}$ cultures have more prominent and very dense-staining amellar bodies in type II cells but few secreted into the air space $(I)$ ), whereas the lamellar bodies of EGF-O explants have a less dense and more amellar appearance and the air space of EGF- $\mathrm{O}_{2}$ explants $(E)$ is filled with surfactant secretions. Note also the swollen appearance of mitochondria $m$ ) in control- $\mathrm{O}_{2}$ explants compared with others and the aberrant cristae within many of the mitochondria. Magnification $\times 9000$. Scale bar $=10$ $\iota \mathrm{m}$. 
Table 2. Effect of EGF (10 nM) on tissue growth parameters in 19-d fetal rat lung explant cultures grown in air or $\mathrm{O}_{2}$ at 72 h*

\begin{tabular}{|c|c|c|c|c|}
\hline Parameter & Control-air & EGF-air & Control- $\mathrm{O}_{2}$ & $\mathrm{EGF}-\mathrm{O}_{2}$ \\
\hline $\begin{array}{l}{ }^{3} \mathrm{H} \text {-thymidine incorporated (dpm/ } \\
\text { mg protein) }\end{array}$ & $\begin{array}{c}44952 \pm 5952 \\
(9)\end{array}$ & $\begin{array}{c}104760 \pm 9000+t \\
(8)\end{array}$ & $\begin{array}{c}53088 \pm 5880 \\
(10)\end{array}$ & $\begin{array}{c}107736 \pm 16104 \dagger t \\
(10)\end{array}$ \\
\hline DNA (mg/plate) & $\begin{array}{l}0.31 \pm 0.08 \\
\quad(10)\end{array}$ & $\begin{array}{l}0.53 \pm 0.16 \dagger \ddagger \\
(10)\end{array}$ & $\begin{array}{l}0.37 \pm 0.14 \\
(10)\end{array}$ & $\begin{array}{c}0.53 \pm 0.08+t \\
\text { (9) }\end{array}$ \\
\hline Protein (mg/plate) & $\begin{array}{l}2.00 \pm 0.58 \\
(10)\end{array}$ & $\begin{array}{l}2.97 \pm 0.91 \dagger \\
(10)\end{array}$ & $\begin{array}{l}2.56 \pm 0.52 \\
\quad(10)\end{array}$ & $\begin{array}{c}4.08 \pm 1.07+48 \\
(9)\end{array}$ \\
\hline Protein/DNA ratio & $\begin{array}{l}6.45 \pm 1.17 \\
(10)\end{array}$ & $\begin{array}{l}5.67 \pm 0.61 \\
(10)\end{array}$ & $\begin{array}{l}7.45 \pm 1.75 \$ \\
(10)\end{array}$ & $\begin{array}{c}7.71 \pm 1.25+\$ s \\
\text { (9) }\end{array}$ \\
\hline
\end{tabular}

* Values are mean \pm SD for number of observations in parentheses. Statistical significance by Duncan's multiple range test.

$\dagger p<0.05$ is control-air.

$\ddagger p<0.05$ is control- $\mathrm{O}_{2}$.

$\S p<0.05$ is EGF-air.

of EGF in the premature lung challenged with hyperoxia. It is also conceivable that increases in AOE activities (and DSPC synthesis) observed in control- $\mathrm{O}_{2}$ cultures in serum-free medium are mediated by a possible EGF-related effect due to local induction of EGF and/or synthesis of other active paracrine factors under hyperoxic conditions. The interesting observation by Tanswell ct al. (41) that medium from fetal lung cell cultures exposed to hyperoxia is capable of increasing AOE activity of lung cells grown in the absence of high $\mathrm{O}_{2}$ concentrations would tend to support such a possibility.

The AOE activity changes in fetal lung explant cultures produced by EGF under hyperoxia were in general accompanied by changes in AOE mRNA levels of similar magnitude. Our study did not definitely elucidate whether the changes were regulated at the transcriptional level or were due to posttranscriptional mechanisms such as changes in mRNA stability. Clerch ot al. $(42,43)$ have recently shown that the normal developmental increases in fetal rat lung CAT activity during late gestation as well as the accelerated rise in fetal lung CAT activity stimulated by prenatal dexamethasone treatment are mediated at the transcriptional level. In contrast, increases in CAT, Cu.ZnSOD, and GP in newborn animal lungs under hyperoxic exposure are brought about primarily by increased stability of AOE mRNA. Chen et al. (26) have found that prenatal thyroid releasing hormone treatment of late gestation rats produced concomitant decreases in fetal lung AOE activities and mRNA with no changes in mRNA half-lives, suggesting again that changes in fetal lung AOE activities are transcriptionally regulated under control and hormone treatment conditions.

In addition to the augmented AOE activities, the increase in DSPC synthesis accompanied by an increase in the surfactant released into the air space in EGF-O ${ }_{2}$ cultures (compared with $\mathrm{O}_{2}$-controls) may have contributed to the protective effect of EGF under hyperoxia. The recent work by Baker 't al. (44) and Matalon et al. (45) has strongly suggested that natural lung surfactant itself may have important antioxidant $\left(\mathrm{O}_{2}\right.$ radicalscavenging) properties.

Another possible explanation for the protection offered by EGF against hyperoxia in our fetal lung cultures is obtained by indirect evidence from the present study as well as direct evidence by others. EGF has been found to increase lactate levels and decrease total $\mathrm{O}_{2}$ consumption in vivo (46), as well as to increase lactate production in vitro in human breast cancer cells (47). In our explant system, total LDH activity in EGF-treated cultures was elevated 2- to 3-fold versus nontreated cultures (control-air $=2865 \pm 461, n=7$; EGF-air $=6413 \pm 537, n=3$; control-O $=2585 \pm 588, n=10 ; \mathrm{EGF} \mathrm{O}_{2}=8253 \pm 2273 \mathrm{U} /$ plate, $\left.n=6\right)$. These marked LDH activity increases indirectly suggest that increases in lactate levels (not measured) may have occurred. Taken together, these facts suggest that EGF treatment may increase glycolysis and decrease $\mathrm{O}_{2}$ consumption at the mitochondrial level, thereby decreasing the production of toxic $\mathrm{O}_{2}$ free radicals under hyperoxia.
Our data on ${ }^{3} \mathrm{H}$-thymidine incorporation and DNA content (Table 2) indicate that EGF induces cell proliferation in lung explant cultures under both normoxic and hyperoxic conditions. Inhibition of DNA synthesis is a frequently reported concomitant of hyperoxic exposure of lung tissue in vitro $(41,16)$ and in vivo (see ref. 4 and references cited therein). Increased cell proliferation is likely to be critical not only for prenatal lung growth but also for repair of $\mathrm{O}_{2}$-induced lung damage. Thus, EGF's ability to induce both greater cell proliferation and cell maturation under hyperoxia may have been an important factor in protecting fetal lung cells exposed to high $\mathrm{O}_{2}$. This dual effect of EGF on lung cell proliferation and maturation contrasts with the well known antiproliferative effect of dexamethasone, whose biochemical effects on fetal lung maturation are quite similar to those of EGF.

Finally, the observation that EGF can induce fetal lung AOE and surfactant increases under hyperoxic conditions may be of particular significance to the $\mathrm{O}_{2}$-requiring premature infant who is susceptible to chronic lung disease (bronchopulmonary dysplasia). EGF could potentially offer a method of postnatal therapy in premature infants with RDS to stimulate an immature $A O E$ defense system to respond protectively to hyperoxic treatment. Similarly, EGF's effect on DSPC synthesis (and secretion) during hyperoxia would be another important potential benefit of EGF treatment. Because EGF is also reported to induce maturation of intestinal mucosa under experimental conditions (48), this could be an added benefit to premature infants in whom early enteral feeding to stimulate gastrointestinal tract maturation is often withheld. Obviously, more studies on these potential benefits as well as possible negative side effects of EGF need to be done before recommending EGF treatment for the respiratory distressed premature infant, but as a natural component of maternal breast milk it could be a very tempting treatment for future clinical consideration.

Acknowledgments. The authors thank Susan J. Decker for her generous assistance with the electron microscopy and electron micrographs and Dr. Luciano Blanco for his advice on preparation of tissue blocks for electron microscopy. We also thank Miguel Martinez for his expert technical assistance and Martha Sanchez for her patient help with the preparation of the manuscript.

\section{REFERENCES}

1. Frank L. Sosenko IRS 1987 Prenatal development of lung antioxidant enzymes in four species. J Pediatr 110:106-110

2. Walther FJ. Wade AB, Warburton D. Forman HJ 1991 Ontogeny of antioxidant enzymes in the fetal lamb lung. Exp Lung Res 17:39-45

3. Frank L 1991 Developmental aspects of experimental pulmonary oxygen toxicity. Free Radic Biol Med 11:463-494

4. Frank L 1985 Effects of oxygen on the newborn. Fed Proc 44:2328-2334

5. Gross I 1990 Regulation of fetal lung maturation. Am J Physiol 259:L337L 344

6. Catterton WZ. Escobedo MB. Sexson WR, Gray ME. Sundell HW. Stahlman 
MT 1979 Effect of epidermal growth factor on lung maturation in fetal rabbits. Pediatr Res 13:104-108

7. Higuchi M, Hirano H. Maki H 1989 Effect of human epidermal growth factor on lung surfactant production in fetal rabbit. Tokoku J Exp Med 159:15-22

8. Plopper CG, St George JA, Read LC Nishio SJ Weir AJ Edwards L. Taranthal AF. Pinkerton KE. Merritt A, Whitsett JA. George-Nascimento C. Styne D 1992 Acceleration of alveolar type II cell differentiation in fetal rhesus monkey lung by administration of EGF. Am J Physiol 262:L313-L321

9. Sundell HW, Gray ME, Serenius FS, Escobedo MB. Stahlman MT 1980 Effects of epidermal growth factor on lung maturation in fetal lambs. Am J Pathol 100:707-726

0. Gross I, Dynia DW, Rooney SA, Smart DA, Warshaw JB, Sissom JF, Hoath SB 1986 Influence of epidermal growth factor on fetal rat lung development in vitro. Pediatr Res 20:473-477

1. Fraslon C, Bourbon JR 1992 Comparison of effects of epidermal and insulinlike growth factors, gastrin releasing peptide and retinoic acid on fetal lung cell growth and maturation in vitro. Biochim Biophys Acta 1123:65-75

12. Iqbal J, Clerch L. Mass M, Frank L. Massaro D 1989 Endotoxin increases Cu, $\mathrm{Zn}$ superoxide dismutase mRNA: hypcroxia needed for increased enzyme synthesis. Am J Physiol 257:L61-L64

3. Rodriguez MP, Sosenko IRS, Antigua MC, Frank L 1991 Prenatal hormone treatment with thyrotropin releasing hormone and with thyrotropin releasing hormone plus dexamethasone delays antioxidant enzyme maturation but does not inhibit a protective antioxidant enzyme response to hyperoxia in newhorn rat lung. Pediatr Res 30:522-527

4. Gross I, Walker-Smith GJ, Maniscalo WM. Czajka MR, Wilson CM, Rooney SA 1978 An organ culture model for study of biochemical development of fetal rat lung. J Appl Physiol 45:355-362

5. Randhwa P. Hass M. Frank L. Massaro D 1986 Dexamethasone increases superoxide dismutase activity in serum-free rat fetal lung organ cultures. Pediatr Res 20:895-898

6. Housset B, Junod AF 1982 Effects of culture conditions and hyperoxia on antioxidant enzymes in pig pulmonary artery and aortic endothelium. Biochim Biophys Acta 716:283-289

7. Richards GM 1974 Modifications of the diphenylamine reaction giving increased sensitivity and simplicity in the estimation of DNA. Anal Biochem 57:369-376

8. Schacterle RE. Pollack RL 1973 A simplified method for quantitative assay of small amounts of protein in biological material Anal Biochem 51:654-655

9. Crapo JD, McCord JM. Fridovich I 1978 Preparation and assay of superoxide dismutases. Methods Enzymol 53:382-393

0. Masters CJ, Holmes RS 1970 Epigenetic interconversion of multiple forms of mouse liver catalase. FEBS Lett 11:45-48

1. Paglia DE, Valentine WN 1967 Studies on the quantitative and qualitative characteristics of glutathione peroxidase. J Lab Clin Med 70:158-169

2. Bligh EG. Dyer WJ 1959 A rapid method of total lipid extraction and purification. Can J Biochem Physiol 37:911-917

3. Mason RJ. Nellenbogen J. Clements JA 1976 Isolation of disaturated phosphatidylcholine with osmium tetroxide. J Lipid Res 17:281-284

4. Morrison WR $1964 \mathrm{~A}$ fast, simple and reliable method for the microdeterm nation of phosphorus in biological materials. Anal Biochem 11:218-224

5. Hass M, lqbal J. Clerch LB, Frank L, Massaro D 1989 Rat lung Cu, Zn superoxide dismutase. Isolation and sequence of a full-length cDNA and studies of enzyme induction. J Clin Invest 83:1241-1246

6. Chen Y, Whitney P. Frank L 1993 Negative regulation of antioxidant gene expression in the developing fetal rat lung by prenatal hormone treatments. Pediatr Res 33:171-176

7. Furuta S, Hayashi H, Hijikata M, Miyazawa S. Osumi T. Hashimoto T 1986
Complete nucleotide sequence of cDNA and deduced amino acid sequence of rat liver catalase. Proc Natl Acad Sci USA 83:313-317

28. Ho Y'-S. Howard AJ. Crapo JD 1988 Nucleotide sequence of a rat glutathione peroxidase cDNA. Nucleic Acids Res 16:5207

29. Fort Ph, Marty L, Piechaczyk M. El Sabrouty S, Dani Ch, Jeanteur $\mathrm{Ph}$ Blanchard JM 1985 Various rat adult tissues express only one major mRNA species from the glyceraldehyde 3-phosphate-dehydrogenase multigenic family. Nucleic Acids Res 13:1431-1442

30. Durnam DM. Palmiter RD 1983 A practical approach to quantitate specific mRNAs by solution hybridization. Anal Biochem 131:385-393

31. Thurlbeck WM. Galaugher W, Mathers J 1981 Adaptive response to pneumonectomy in puppies. Thorax 36:414-427

32. Weibel ER 1963 Morphometry of the Human Lung. Academic Press, New York, pp 5i-73

33. Duncan DB 1955 Multiple range and multiple F tests. Biometrics 11:1-42

34. Kramer CY 1956 Extension of multiple range tests to group means with unequal number of replications. Biometrics $12: 307-310$

35. Warshaw B, Jamison TS, Sissom JF 1985 EGF decreases lung glycogen and stimulates lung phosphatidyl choline synthesis in fetal rat. Pediatr Res 19:165A(abstr)

36. Federspiel SJ, DiMari SJ, Howe AM, Guerry-Forer ML Haralson M 199 Extracellular matrix biosynthesis by cultured fetal rat lung epithelial cells. III. Eflects of chronic exposure to epidermal growth factor on growth differentiation, and collagen biosynthesis. Lab Invest 64:463-473

37. Frank L 1992 Prenatal dexamethasone treatment improves survival of newborn rats during prolonged high $\mathrm{O}_{2}$ exposure. Pediatr Res 32.215-221

38. Frank L. Summerville J, Massaro D 1980 Protection from oxygen toxicity with endotoxin: role of endogenous antioxidant enzymes of the lung. $\mathrm{J} C$ lin Invest 65:110\$-1110

39. Frank L. Bucher JR. Roberts RJ 1978 Oxygen toxicity in neonatal and adult animals of various species. J Appl Physiol 45:699-704

40. Frank L. Sosenko IRS 199! Failure of premature rabbits to increase antioxidant enzymes during hyperoxic exposure: increased susceptibility to pulmonary oxygen toxicity compared with term rabbits. Pediatr Res 29:292-296

41. Tanswell AK. Tzaki MG, Byrne PJ 1986 Hormonal and local factors influence antioxidant enzyme activity of rat fetal lung cells in vitro. Exp Lung Res 11:49-59

42. Clerch LB, Iqbal J. Massaro D 1991 Perinatal rat lung catalase gene expression: influence of corticosteroid and hyperoxia. Am J Physiol 260:L428.L433

43. Clerch LB. Iqbal J. Massaro D 199! Rat lung catalase gene expression is regulated transcriptionally during late gestation but by a post-transcriptional increase in mRNA stability during postnatal hyperoxia. FASEB 5:A1055(abstr)

44. Baker RR, Holm BA, Panus PC, Matalon S 1989 Development of $\mathrm{O}_{2}$ tolerance in rabbits with no increases in antioxidant enzymes. J Appl Physiol 66:16791684

45. Matalon S, Holm BA, Baker RR, Whitfield MK, Freeman BA 1990 Characterization of antioxidant activitics of pulmonary surfactant mixtures. Biochim Biophys Acta 1035:121-127

46. Donnelly MM. Hoath SB. Pickens WF 1992 Early metabolic consequences of epidermal growth factor administration to neonatal rats. Am J Physiol 263:E920-E927

47. Kaplan O, Jaroszewski JW, Faustino PJ, Zugmaier G. Ennis BW, Lippman M, Cohen JS 1990 Toxicity and effects of epidermal growth factor on glucose metabolism of MDA-468 human breast cancer cells. J Biol Chem 265:13641 13649

48. Malo C. Menard D 1982 Influence of epidermal growth factor on the development of suckling mouse intestinal mucosa. Gastroenterology $83: 28-35$ 